\title{
DRUG REPURPOSING FOR SNAKE BITE: AN INSILICO INVESTIGATION
}

\author{
Nnoruka, Udoka Chukwudubem \\ Department of Biochemistry \\ University of Port Harcourt, Port Harcourt, \\ Rivers State, Nigeria
}

\begin{abstract}
Snake bite is a major neglected public health issue within poor communities living in rural areas of several countries throughout the world. An estimated 2.5 million people are bitten by snakes each year and the cost and lack of efficacy of current anti-venom therapy together with the lack of detailed knowledge about toxic components of venom and their modes of action, and the unavailability of treatment in rural areas mean that annually there are around 125,000 deaths worldwide. In other to develop cheaper and more effective therapeutics, the toxic components of snake venom and their modes of action need to be clearly understood. One particularly poorly understood component of snake venom is phospholipase A2. These are enzymes which in mammals are involved in vascular inflammation correlating with coronary events in coronary artery disease and acute coronary syndrome and possibly leading to acute respiratory distress syndrome. Although phospholipase A2 activities have been reported in some snake venoms, no detailed analysis of any individual snake venom phospholipase A2 has been performed so far. Through the use of docking process, a tool in Insilico investigation, already approved drugs were tested for binding affinity to the active site of snake phospholipase A2, to detect which can be used to inhibit snake phospholipase A2. 25 of the sampled drugs exhibits higher affinity than the control (lupeol), thus, considered having anti-venom properties as such recommended for integration into health care.
\end{abstract}

Keywords- Drug, Repurposing, Snake bite, insilico investigation.

\section{INTRODUCTION}

Most snake bites are caused by non-venomous snakes of the roughly 3,000 known species of snake found worldwide, only $15 \%$ are considered dangerous to humans (Kasturiratne et al., 2008). Snakes are found in every continent except Antarctica (Kasturiratne et al., 2008). There are two major families of venomous snakes, Elapidae and Viperidae. Three hundred and twenty five species (325), in sixty one (61) genera are recognized in the family Elapidae and two hundred and twenty four (224) species in twenty-two genera are recognized in the family Viperidae (integrated taxonomic information system,
2006). In addition, the most diverse and widely distributed snake family, the colubrids, has approximately 700 venomous species (Mackessy, 2002), but only five (5) generaboomslangs, twig snakes, keel back snakes, green snakes and slender snakes have caused human fatalities (Mackessy, 2002).

Since reporting is not mandatory in regions of the world, snake bites can go unreported. Consequently, no accurate study has ever been conducted to determine the frequency of snake bites on the international level. However, some estimates put the number at 5.4 million snake bites, 2.5 million Envenoming, resulting in perhaps 125,000 deaths (Kasturiratne et al., 2008). Others estimated 1.2 to 5.5 million snake bites, 421,000 to 1.8 million envenomings and 20,000 to 94,000 deaths (Karir et al., 2015).

Many people who survive bites nevertheless suffer from permanent tissue damage caused by venom leading to disability (Gutierrez et al., 2007). Most snake envenomings and fatalities occur in South Asia, South East Asia and subSahara Africa, with India reporting the most snake bite deaths of any country (Kasturiratne et al., 2008).

Although, Africa is home to four venomous snake families Atractaspididae, colubridae, Elapidae and Viperidae approximately 605 of all bites are caused by vipers only Mackessy, 2002). In drier regions of the continents, such as sahels and Savannas, the saw-scaled vipers inflict up to $90 \%$ of all bites (Mackessy, 2002). The black mamba, although responsible for far less snake bite incidents, is the species which has the highest mortality rate in Africa and in the world (Van Der Vlies, 2010).

In sub-Sahara Africa, over $50 \%$ of snake bite injuries are not appropriately treated (Mackessy, 2002). Between $40 \%$ and $80 \%$ of victims, depending on the country, exclusively rely on traditional medicine for treatment (Mackessy, 2002). In many sub-Sahara countries, poor availability of expensive antivenom contributes to morbility, and snake bites continue to remain a neglected health problem (Mackessy, 2002).

Sequel to the poor availability of antivenom and it expensive nature, there comes the need to initiate a conventional means of handling snake bite, and this can be best achieved through drug repurposing. Drug repurposing is one such strategy, many agents approved for other uses already have been tested in humans, so detailed information is available on their pharmacology, formulation and potential toxicity. Because 


\section{International Journal of Engineering Applied Sciences and Technology, 2019 Vol. 4, Issue 7, ISSN No. 2455-2143, Pages 42-48 \\ Published Online November 2019 in IJEAST (http://www.ijeast.com)}

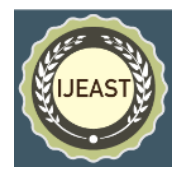

repurposing builds upon previous research and development efforts, new candidates therapies could be ready for clinical trials quickly, speeding their review by the food and drug administration and if approved, their integration into health care.

\section{MATERIALS AND METHOD}

During the course of this project, certain materials were used. They include;

\section{Hardware (Computer System)}

This is the major material needed for this research and was bought from Obejor communications Nnewi, Anambra State, Nigeria.

\section{Software}

Series of software were used for the research work and were gotten from Obejor communications Nnewi, Anambra State, Nigeria.

These softwares include:

Linus operating system: This is operating system software that serves as the platform for the molecular docking simulation.

Auto dock tool: used in the preparation of ligands.

Chimera: used in preparing the receptor.

Pymol: used in viewing of the binding pockets during validation.

Auto dock Vina: used for the molecular docking simulation.

\section{Bioinformatics Data Mining Tools}

These are banks of information through which already established facts were obtained. They include:

Google: A research tool which serves as an interface for sourcing all internet based information.

Protein data bank: A bioinformatics data mining tool from which the receptor was obtained.

Drug bank: A bioinformatics data mining tool from which the ligands were obtained.

Molinspiration: Used to obtain the biological activities of the ligands.

Zinc data bank: A bioinformatics data mining tool from which the physiological parameters and structures of ligands were obtained.

\section{METHODS}

Several steps and techniques were employed for the success of this research work.

\section{Selection of Ligands (Approved Clinical Drugs)}

The drugs were generated from drug bank (www.drugbank.com). Approved drugs were filtered and used to query zinc data base to obtain there physiological parameters (Smiles file format, $\mathrm{X} \log \mathrm{P}, \mathrm{H}$-bond donor, $\mathrm{H}$ bond acceptor, rotatable bonds, topological polar surface area).

Using the smiles file format, molinspiration was opened and the smile file was pasted to obtain the biological activities (Gcoupled protein receptor ligand, Ion channel modulator, kinase inhibitor, nuclear receptor ligand, protease inhibitor, enzyme inhibitor).

The structures of these approved drugs were gotten from zinc data base in mole file extension.

\section{Preparation of Ligands (Approved Clinical Drugs)}

The downloaded structures of drugs were prepared using an Autodock tool.

The ligand (drug) of study was called into the autodock interface by clicking on "file" icon and "read molecule". This gives an interface to browse through to locate the ligand of interest and was right clicked on to open.

Hydrogen was added to the ligand by clicking "Edit", "hydrogen", "add hydrogen" and "Ok".

The number of rotatable bonds was set to ensure it does not exceed the maximum autodock tool can handle, that is 32 rotatable bonds.

The root detected by clicking "ligand" "Torsion tree" and "detect root" after which the torsion is being chosen and the icon "Done" is clicked.

The prepared ligand is saved by clicking on "ligand", "Output" and the "Save as PDBQT".

Selection of the receptor (Phospholipase A2)

Receptors are gotten from protein data bank (PDB). Google interface was opened and "Protein Data bank" typed into the search panel. This launched the PDB where the receptor was generated from.

Each receptor is given a four Alpha numeric PDB ID e.g. 1YXL and 3NJU. Knowing that the PDB ID of the receptor of interest is $3 \mathrm{NJU}, 3 \mathrm{NJU}$ was typed into the search panel, this brought forward the structure of phospholipase A2 needed.

The structure with a lower resolution is preferred because the smaller the resolution, the better the structure.

NOTE: It is better to use a receptor with a ligand because it will serve as control.

The structure of interest was downloaded as PDB file (Text).

Preparation of Receptor (Phospholipase A2)

The downloaded receptor was prepared using chimera and Autodock tool

\section{a. Using Chimera}

The icon "file" was clicked and an interface was opened to enable browsing through the documents where the receptor saved as 3NJU was called in by clicking "open".

\section{To Determine the Number of Chain}

"Select" icon was clicked and then "chain", one chain was detected, making it acceptable, then "OK" was clicked. If the chain happens to be two or above, the extra chain(s) will be deleted leaving only one.

\section{Deletion of the Residues}

To delete the residues present, "select" icon was clicked, then "residue", calcium, water and ANN was detected. "HOH" was selected followed by CA by clicking on them, followed by "Action", "Atoms/Bonds" and then "Delete". Having deleted water and calcium, the receptor with ANN was saved by clicked on "file", "save PDB" and was saved as 3nju-ann. 


\section{International Journal of Engineering Applied Sciences and Technology, 2019 Vol. 4, Issue 7, ISSN No. 2455-2143, Pages 42-48 \\ Published Online November 2019 in IJEAST (http://www.ijeast.com)}

To delete the ligand ANN, the receptor with the ligand only i.e. 3ju-ann was called into the chimera interface, "select" was clicked on, then "residue", "ANN", "Action", "Atoms/"Bond" and "Delete". The resulting structure was then saved as 3njuedited.

\section{b. Using Autodock Tool}

The edited receptor was called into the autodock tool by clicking "file", "Read molecule", this gave an interface where edited receptor was opened.

To add charges:

"Edit" was clicked, then "Charges", "Add Kollman charges" and finally "Ok".

To add Hydrogen

"Edit" was clicked, then "Hydrogen", 'Add", "polar only" and "Ok".

\section{Treating the Receptor as a Rigid Molecular}

"Grid" icon was clicked followed by "Macromolecule", "choose", the molecule was selected and "OK" and "Save" was clicked.

The spacing was changed to 1 and sizes of $\mathrm{X}$-dimension, $\mathrm{Y}$ dimension and Z-dimension were changed to 25, 28 and 25 respectively, and center value of the dimension noted.

This information was used to prepare a configuration file which was used to write a script for the docking process.

Configuration file

$\begin{array}{lll}\text { Receptor } & = & \text { 3nju-edited pdbqt } \\ \text { Center - x } & =-1.922 \\ \text { Center - y } & =-11.229 \\ \text { Center - Z } & =-0.271 \\ \text { Size }-\mathrm{x} & =25 \quad=28 \\ \text { Size - } & \mathrm{y} \quad=25 \\ \text { Size - } & \mathrm{Z} \quad=\end{array}$

\section{Validation of molecular Docking simulation}

The original receptor obtained from Pdb (Protein Data Bank) containing Ann was visualized using Chimera, to obtain the amino acids present.

The receptor was edited, removing the Ann, a free Ann was obtained from Drug bank and was docked to the edited receptor. The new receptor was also visualized using Chimera to ensure that the amino acids were duplicated.

\section{Molecular Docking Simulation}

In the field of molecular modeling, docking is a method which predicts the preferred orientation of one molecule to a second when bound to each other to form a stable complex (Lengaver and Rarey, 1996).

Docking is frequently used to predict the binding orientation of small molecule drug candidates to their protein targets in order to in turn predict the affinity and activity of the small molecule. Hence docking plays an important role in the rational design of drugs (Kitchen et al., 2004).

Using the configuration file above, a script was written, which was used to predict the affinity of the ligands to the receptor on autodock Vina software using a Linus platform.
The docking process was done three times to obtain three values for each ligand, this is to ensure consistency and accuracy and the values tabulated.

\section{RESULT AND DISCUSSION}

From the insilico investigation conducted on 213 clinically approved drugs (ligands) to determine their affinity level to snake phospholipase A2, the following results were obtained.

Selection of Clinically Approved Drugs Result Table 1: Drugs with higher affinity than the control (lupeol)

\begin{tabular}{|l|l|l}
\hline Name of Drug & Zinc code & Average \pm Std.Dev(Kcal/mol) \\
\hline Dutasteride & 14880001 & $-9.60 \pm 0.082$ \\
\hline Ciclesonide & 36047107 & $-9.50 \pm 0.000$ \\
\hline Formestane & 3977753 & $-8.80 \pm 0.000$ \\
\hline Norelgestromin & 34142545 & $-8.80 \pm 0.000$ \\
\hline Fulvestrant & 26265317 & $-8.63 \pm 0.150$ \\
\hline Stanozolol & 3873362 & $-8.63 \pm 0.050$ \\
\hline Masoprocol & 1539579 & $-8.60 \pm 0.346$ \\
\hline $\begin{array}{l}\text { Conjugated } \\
\text { estrogens }\end{array}$ & 3830788 & $-8.60 \pm 0.000$ \\
\hline Nabilone & 1542930 & $-8.53 \pm 0.050$ \\
\hline $\begin{array}{l}\text { D-Norgestrel } \\
\text { Oxime }\end{array}$ & 3973186 & $-8.50 \pm 0.000$ \\
\hline Bexarotene & & $-8.45 \pm 0.300$ \\
\hline $\begin{array}{l}\text { Nandrolone } \\
\text { Phenylpropionate }\end{array}$ & 3881613 & $-8.35 \pm 0.058$ \\
\hline Estrone & 13509425 & $-8.23 \pm 0.050$ \\
\hline Norgestimate & 3938695 & $-8.18 \pm 0.050$ \\
\hline Estriol & 3815418 & $-8.10 \pm 0.000$ \\
\hline Finasteride & 3830838 & $-8.08 \pm 0.050$ \\
\hline Ecabet sodium & 3779720 & $-8.03 \pm 0.050$ \\
\hline Mestranol & 71789838 & $-8.00 \pm 0.000$ \\
\hline Sulindac & 16694163 & $-8.00 \pm 0.000$ \\
\hline Megestrol Acetate & 12655011 & $-7.93 \pm 0.050$ \\
\hline Dihydrotachysterol & 4212953 & $-7.90 \pm 0.000$ \\
\hline Methylprednisolone & 3881946 & $-7.90 \pm 0.000$ \\
\hline Oxaprozin & 1863 & $-7.83 \pm 0.050$ \\
\hline Lupeol & $\mathbf{6 3 0 3 8 9 1}$ & $-\mathbf{7 . 8 0} \pm \mathbf{0 . 0 0 0}$ \\
\hline From Tab & & \\
\hline
\end{tabular}

From Table 1 above, Dutasteride and Ciclesonide have been shown to have greater affinity to phospholipase A2.

The result above is presented in average of four dock values \pm standard deviation

Validation of Molecular Docking Simulation Result 


\section{International Journal of Engineering Applied Sciences and Technology, 2019 \\ Vol. 4, Issue 7, ISSN No. 2455-2143, Pages 42-48 \\ Published Online November 2019 in IJEAST (http://www.ijeast.com)}

Table 2: Amino acids present in original receptor and in docked receptor

\begin{tabular}{|c|c|}
\hline $\begin{array}{ll}\begin{array}{l}\text { Original } \\
\text { (3nju_Ann) }\end{array} & \text { receptor } \\
\end{array}$ & Docked receptor (3nju_ann) \\
\hline Tyrosine 64 & Tyrosine 64 \\
\hline Glycine 30 & Glycine 30 \\
\hline Aspartate 49 & Aspartate 49 \\
\hline Tyrosine 52 & Tyrosine 52 \\
\hline Leucine 2 & Leucine 2 \\
\hline Histidine 48 & Histidine 48 \\
\hline Phenyl alanine 5 & Phenyl alanine 5 \\
\hline Tryptophan 19 & Tryptophan 19 \\
\hline Phenyl alanine 22 & Phenyl alanine 22 \\
\hline Phenyl alanine 101 & Phenyl alanine 101 \\
\hline Cysteine 29 & Cysteine 29 \\
\hline Tyrosine 28 & Tyrosine 28 \\
\hline \multirow[t]{3}{*}{ Lysine 31} & Lysine 31 \\
\hline & Isoleucine 9 \\
\hline & Lysine 6 \\
\hline
\end{tabular}

Table 2 above shows the result obtained in validating the docking process, it shows that all the amino acid present in the original ligand-receptor complex was duplicated in the docked complex. With this it can be said that the protocol was near $100 \%$ efficient.

Fig 1: Validation binding pockets
Fig 1 shows that both the original (white) and the docked (green) bind at the same binding pocket.

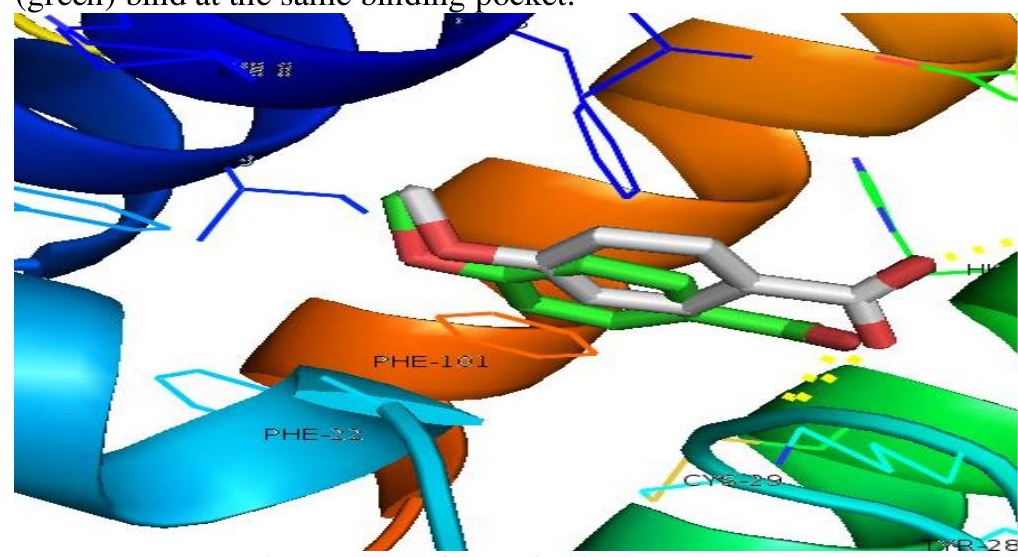

Fig 2: View of the binding pockets

Fig. 2 shows the result of the binding site of the original ANN and generated ann on phospholipase A2 when viewed using pymol, hence showing that the two targeted same binding site.

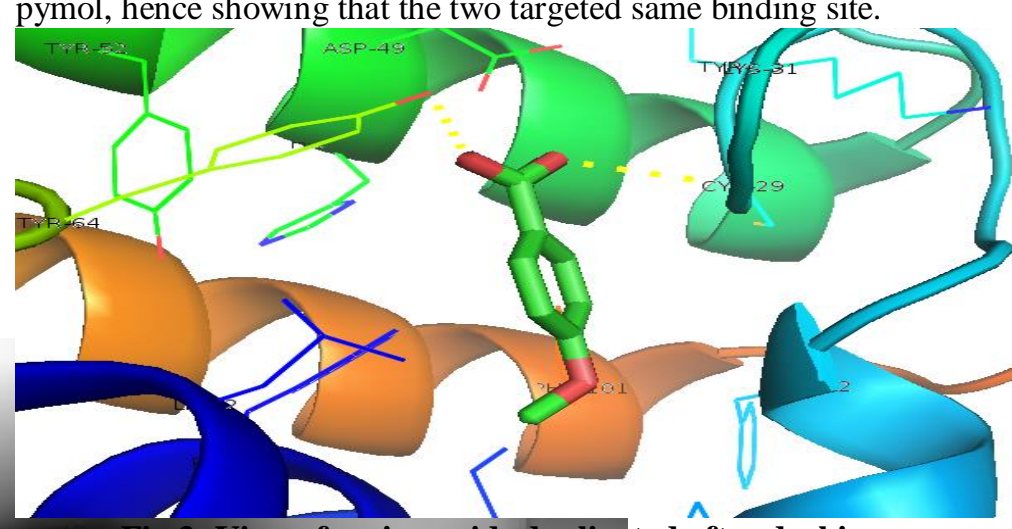

View of amino acids duplicated after docking

Fig 3 shows the amino acids duplicated during validation of docking protoce

\section{Discussion}

Repurposing has indeed proven to be a fast, reliable and good approach towards drug discovery and application of known drugs and compounds to new indications (Sleigh and Barton, A significant advantage of drug repurposing over traditional drug development is that since the repositioned drug has already passed a significant number of toxicity and other tests, its safety is known and the risk of failure for reasons of adverse toxicology are reduced (Dimasa et al., 1991). Repurposed drugs bypass much of the early cost and time needed to bring a drug to market (Dimasa et al., 1991).

In this study, repurposing was carried out to determine approved drugs that can have new indication of inhibiting the actions of snake venom. This has been a world problem as anti-venom are rare and expensive if not unavailable. 


\section{International Journal of Engineering Applied Sciences and Technology, 2019 Vol. 4, Issue 7, ISSN No. 2455-2143, Pages 42-48 \\ Published Online November 2019 in IJEAST (http://www.ijeast.com)}

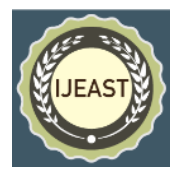

213 approved drugs were analyzed insilico using a type of molecular modeling known as Docking. Docking is a method which predicts the preferred orientation of one molecule to a second when bound to each other to form a stable complex (Lengaver and Rarey, 1996). Using Lupeol as a standard or control, 25 of these approved drugs showed greater affinity for phospholipase A2 thus showing their potentiality in the treatment of snake bite. Dutasteride and Ciclesonide have been shown to be leading in affinity to phospholipase A2. These drugs can be integrated into health care if proper investigations are done on them Invivo and Invitro. Dutasteride is a triple $5 \alpha$-reductase inhibitor that inhibits conversion of testosterone to dihydrotestosterone (DHT) (Yamana et al., 2010). It is used in the treatment of benign prostatic hyperplasia (BPH); colloquially known as an "an enlarged prostrate" (Slater et al., 2012). It increases the risk of erectile dysfunction (Gur et al., 2013) and decreased sexual desire (Traish et al., 2011). Dutasteride has 99\% protein binding affinity (Wilt et al., 2008), this is considered to possibly be the reason for the high affinity to phospholipase A2.

Ciclesonide is a glucocorticoid used to treat asthma and allergic rhinitis. The drug was approved for adults and children 12 and over by the US Food and Drug Administration in October 2006 (FDA News Release, 2006). Side effects of the medication include headache, nosebleeds, and inflammation of the nose and throat linings (Mutch et al., 2007).

\section{CONCLUSION}

Conclusively, snake bite should as a matter of urgency be seen as a world medical emergency. As such, these 25 potential anti-snake venom obtained especially the leads; Dutasteride and Ciclesonide should be incorporated into health care since their pharmacokinetic parameters have been known.

There is no end to research, science is evolving and there is no absolute truth in science. Bearing this in mind, further study on the half-life, adverse effects, bioavailability, toxicity and other parameters should be carried out for subsequent screening to obtain the best out of these potential 25 antisnake venom. In vivo and Invitro experiments is encouraged to further determine the efficacy of these potential anti-snake venom.

\section{ACKNOWLEDGEMENT}

Appreciation goes to all who in one way or the other assisted in making this project a success and to the authors whose works were reviewed.

\section{REFERENCE}

1. Argiolas, A. and Pisano, J. (1983). "Facilitation of Phospholipase A2 Activity by Mastoparans, a new class of most cell Degranulating Peptides from Wasp Venom" (PDF). J. Biol. Chem. 258(22): 13697-702.

2. Athanaileas, T. (2011). "Exploiting Grid Technologies for the Simulation of Clinical Trials: the Paradigm of Insilico Radiation Oncology". SIMULATION: Transactions of The Society for Modeling and Simulation International (Sage Publications)87 (10): 893-910.

3. Bauchot, R. (1994). Snakes: A Natural History. NewYork City, NY, USA: Sterling Publishing Co.,Inc. pp 194-209

4. Bottrall, J.,Frank, M.,Christopher, D., Michael,G. and Peter,J. (2010). Proteolytic Activity of Elapid and Viperid Snake Venoms and its Implication to Digestion". Journal of Venom Research1(3): 18-28.

5. Chalbot, S., Zetterberg, H., Blennow, K., Fladby, T., Andreasen, N., Grundke- Igbal, I. and Igbal, K. (2011). "Blood cerebrospinal fluid barrier Permeability in Alzheimer's Disease" Journal of Alzheimer's Disease 25 (3): 505-15.

6. Condrea, E., De Vries, A. and Mager, J. (1964). "Hemolysis and Splitting of Human Erythrocyte Phospholipids by Snake Venoms". Biochimica et Biophysica Acta (BBA) -Specialized Section on Lipids and Related Subjects 84(1):60-73.

7. Cox, M., Nelson, D. and Lehninger, A. (2005). Lehninger principles of biochemistry $\left(4^{\text {th }}\right.$ ed). San Francisco: W.H. Freeman.

8. Dantas, G., Kuhlman, B., Callender, D., Wong, M. and Baker, D. (2003). "A Large Scale Test of Computational Protein Design: Folding and Stability of Nine Completely Redesigned Globular Protein”. Journal of Molecular Biology332 (2): 449.

9. Deluca, D., Minucci, A. Logo, P., Capoluongo, E., Conti, G., Pietrini, D., Carnielli, V. and Piastra, M. (2011). "Secretary Phospholipase A2 Pathway during Pediatric Acute Respiratory Distress Syndrome". International Journal of Pediatric Otorhinolaryngology76 (5) 533-6.

10. Dennis, E.A.(1994). "Diversity of group types, regulation, and function of phospholipase A2". $J$. Biol. Chem. 269(18):13057-60.

11. "Drug". Dictionary.com unabridged (VI.I), Random House, Inc,via dictionary.com. Retrieved on 20 September 2007 


\section{International Journal of Engineering Applied Sciences and Technology, 2019 \\ Vol. 4, Issue 7, ISSN No. 2455-2143, Pages 42-48 \\ Published Online November 2019 in IJEAST (http://www.ijeast.com)}

12. "Drug". The American heritage Science Dictionary, Houghton Mifflin Company, via dictionary.com. Retrieved on 20 September 2007

13. Escoffier, J., Jemel, I., Tanemoto, A., Payre, C., Coatrieux, C., Sato, H. and Yamamoto, K. (2010). "Group x phospholipase A2 is released during sperm acrosome reaction and controls fertility outcome in mice". JournalofClinicallnvestigation120(5):141528.

14. Ezzeddini, R., Darabi, M., Ghasemi, B., Jabbari, Y., Abdollahi, S., Rashtchizadeh, N., Glarahdaghi, A., Darabi, M., Ansarin, M., Shaaker, M., Samadi, A. and Karamravan, J. (2012). "Circulating Phospholipase A2 Activity in Obstructive Sleep apnea" International Journal of Pediatric Otorhinolaryngology76(4):472-4.

15. "Fox, T.P., Oliver, G. and Ellis, S.M.(2013). The Destructive Capacity Of Drug Abuse: An Over View Exploring The Harmful Potential Of Drug Abuse Both To The Individual And To Society. ISRN Addiction 2013. Retrieved 15 April 2015.

16. Fredriksson,G.N.(2005).'Predation on sun Bears by reticulated Python in East Kalimantan, Indonesian Borneo". RafflesBulletinofZoology53 (1):165-168.

17. Fry, B., Vidal, N., Norman, J., Vonk, J., Scheib, H., Ramjan, S., Ryan, K., Fung, K., Hedges, S., Richardson, K., Hodgson, W., Vera, I., Summerhayes, R. and Kochva, E.(2006).Early evolution of the venom system in lizards and snakes. Nature (letters)439 (7076): 584-588.

18. Gutierrez, J.M., Bruno, L., Guillermo, L., Alexander, R., Fernando, C. and Yamileth, A. (2007). Trends in Snakebite Envenomation Therapy: Scientific, Technological and Public Health Considerations (PDF). Current Pharmaceutical Design13(28):2935-50.

19. Halliday,A. and Tim, K. (2002). Firefly Encyclopedia of Reptiles and Amphibians. Toronto, Canada:Firefly Books Ltd.pp.202-203.

20. Head,Jason, J., Jonathan, I.B., Alexander, K.H., Jason,R.B., Edwin, A.C.,Fabiany, A.H., David,P.P. and Carlos, A .J. (2009). Giant BoidSnake from the Paleocene Neotropics Reveals Hotter Past Equatorial Temperatures. Nature457:715-718.

21. Henderson, W.J., Oslund, R., Bollinger, J., Ye, X., Tien, Y., Xue, J. and Gelb, M. (2011). "Blockage of Human Group x Secreted Phospholipase A2 (GXsPLA2) - Induced Airway Inflammation and Hyperresponsiveness in a Mouse Asthma Model by a Selective GX-sPLA2 Inhibitor". Journal of Biological Chemistry286 (32): 28049-55.
22. Kadir, M.F., Karmoker, J.R., Alam, M.R., Jahan, S.R., Mahbub, S. and Mia, M.M.K. (2015). Ethnopharmacological Survey of Medicinal Plans used by Traditional Healers and Indigenous People in Chittagong Hill Tracts, Bangladesh, for the Treatment of Snakebite. Evidence-based Complementary and Alternative Medicine 1-23.

23. Kasturiratne, A., Wickremasinghe, A.R., Desilva, N., Gunawardena, N.K. and Pathmeswaran, A. (2008). The Global Burden of Snake bite: A Literature Analysis and Modellling Based on Regional Estimates of Envenoming and Deaths. PLDS Medicine, 5(11):e218.

24. Kitchen, D.B., Docornez, H., Furr, J.R. and Bajorath, J. (2004). Docking and Scoring in Virtual Screening for Drug Discovery: Methods and Applications, Nature Reviews. Drug Discovery3(11):935-49.

25. Lengaver, T. and Rarey, M. (1996). Computational Methods for Bimolecular Docking. Current Opinion Structure Biology6(3): 402-6.

26. Leslie, C.C. (1997). "Properties and regulation of cytosolic phospholipase A2". J. Biol. chem. 272(27): $16709-12$.

27. Li, S., Brazhnik, P., Sobral, B. and Tyson, J. (2009). "Temporal Controls of the Asymmetric cell Division cycle in Caulobactercrescentus". Plos comput Biol5(8): e1000463.

28. Ludwig Institute for Cancer Research (2010). New computational Tool for Cancer Treatment. Science Daily. Retrieved February 12, 2010.

29. Mackessy, S.P. (2002). Biochemistry and Pharmacology of Colubrid Snake Venoms (PDF). Journal of Toxicology: Toxin Reviews21(1-2):4383.

30. Mallat, z., Lambeau, G. and Tedgui, A. (2010). "Lipoprotein Associated and Secreted Phospholipase A2 in Cardiovascular Disease: Roles as Biological Effectors and Biomarkers". Circulation122 (21): $2183-2200$.

31. Martin, C. and Lamb, G. (1907). "Snake poison and snake- bite" In Allbutt, T.C., Rolleston N.D.A system of medicine. London: Macmillan. Pp. 783-821.

32. Mattison, C.(2007). The New Encyclopedia of Snakes. New Jersey, USA: Princeton University Press.p.117.

33. Mehrtens, J.M. (1987). Living Snakes of the World in Color. NewYork: Sterling Publishers.480pp.

34. Nicolas, J., Lin, Y., Lambeau, G., Ghomashchi, F., Lazdunski, N.andGelb, M. (1997). "Localization of Structural Elements of Bee Venom Phospholipase A2 


\section{International Journal of Engineering Applied Sciences and Technology, 2019 \\ Vol. 4, Issue 7, ISSN No. 2455-2143, Pages 42-48 \\ Published Online November 2019 in IJEAST (http://www.ijeast.com)}

Involved in $\mathrm{N}$ - Type Receptor Binding and Neurotoxicity". J.Boil Chem.272 (II): 7173-81.

35. Perkins, S.(2015). Fossils of oldest known snakes unearthed. News.sciencemag.org. Retrieved 29 January 2015.

36. Reader, T.W., Townsend, T.M., Mulcahy, D.G., Noonan, B.P., Wood, P.L., Sites, J.W. and Wiens, J.J. (2015). Integrated Analyses Resolve Conflicts over Squamate Reptile Phylogeny and Reveal Unexpected Placement for $\quad$ Fossil Taxa.PLOSONE10(3):e0118199.

37. Rodriguez-lthurralde, D., Silueira, L. and Barbeito, F. (1983). :Fasciculin, a Powerful Anticholinerase Polypeptide from Dendroaspisangusticeps Venom". Neurochemistry International5(3):267-274.

38. Rohrig, U., Awad, L., Grosdidier, A., Larrieu, P., Stroobant, V., Colau, D., Cerundolo, V. and Simpson, A. (2010). "Rational Design of Indoleamine 2,3-Dioxygenase Inhibitors". Journal of Medicinal Chemistry 53(3): 1172-89.

39. Roland, B. (1994). Snakes: A Natural History. NewYork: Sterling publishing co.,Inc.P.220.

40. Rosenberg, C.(2011). "Bill Haast Dies at 100; Snakes were the Charm for South Florida Celebrity. Log Angeles Times. Retrieved 2012-10-16.

41. Sato, H., Taketomi, Y., Isogai, Y., Yamamoto, K., Nasada, S., Tomohiko, H. and Arata, S. (2010). "Group x Phospholipase A2 is Released during Sperm Aerosome Reaction and Controls Fertility Outcome in Mice". Journal of Clinical Investigation 120 (5): 1415-28.

42. Schudel, M. (2011). "Bill Haast dies at 100: Florida snake man provided venom for snakebite serum". TheWashingtonpost. Retrieved 2012-10-16.

43. Six, D.A. and Dennis, E.A. (2000). "The Expanding Super-family of Phospholipase A2 Enzymes. Classification and Characterization. Biochim. Biophys. Acta1488(1-2): 1-19.

44. Sleigh, S.H. and Barton, C.L. (2010). Repurposing Strategies for Therapeutics. Pharm Med24(3):151159.

45. Tupper, K.W.(2012). Psychoactive substances and the English language."Drugs", discourses and public policy. Contemporary Drug Problems,39(3); 461472.

46. Van Der Vlies, C. (2010). Southern African Wildlife and Adventure. British Columbia, Canada/Indiana, United States: Trafford Publishing. Pp. 180-181. 